\title{
Tap water as a wound cleansing agent in accident and emergency
}

\author{
M S Riyat, D N Quinton
}

\begin{abstract}
Objective-To investigate the bacterial cleanliness of tap water in a large accident and emergency (A\&E) department for its possible use in the cleansing and irrigation of open traumatic wounds.

Methods-Tap water samples were collected from different areas within the department and analysed on two separate occasions for coliforms, $S$ aureus, clostridia, pseudomonas, and $\beta$ haemolytic streptococci.

Results-Pathogenic bacteria were not isolated from the tap water samples within the A\&E department.
\end{abstract}

Conclusions-Tap water of drinking quality can be used to irrigate open traumatic wounds.

(F Accid Emerg Med 1997;14:165-166)

Keywords: tap water; wound cleansing; traumatic wounds

The Leicester Royal Infirmary accident and emergency (A\&E) department treats approximately 16500 patients (approximately 15\% of the total annual workload) with open traumatic wounds each year. The aim of treating these wounds is to encourage wound healing and prevent infection. All open traumatic wounds are contaminated at presentation to the $A \& E$ department and usually require debridment and thorough irrigation to remove loose debris. ${ }^{12}$ Irrigation of wounds also removes loose devitalised tissue and has been shown to reduce the infection rate in contaminated wounds. ${ }^{3-5}$ Unfortunately the best choice of irrigation fluid is still unclear. Many wound cleansing agents have been used routinely in the past, including hydrogen peroxide, povidine-iodine, Dakin's solution, and Hibiclens. However, these solutions do not differentiate bacteria from new fibroblasts and have been shown to retard healing. ${ }^{67}$ At present such wounds are cleaned and irrigated with normal saline, either from a single sachet or from a multidose bottle. If tap water could be used to irrigate these contaminated traumatic wounds it would be easier and save money.

\section{Methods}

In the United Kingdom, drinking water supplies are usually connected directly to the mains water supply, while the other hot and cold water taps are supplied from water storage tanks within the building. Tap water samples were collected from different areas within the A\&E department. They included drinking
Table 1 Bacterial colony count of A\&E tap water in the first sample group

\begin{tabular}{|c|c|c|}
\hline$A \mathcal{E} E$ areas investigated & $\begin{array}{l}\text { Colony count } / \mathrm{ml} \mathrm{at} \\
22^{\circ} \mathrm{C}\end{array}$ & $\begin{array}{l}\text { Colony count } / \mathrm{ml} \text { at } \\
37^{\circ} \mathrm{C}\end{array}$ \\
\hline Ward hot water & 0 & 0 \\
\hline Ward cold water & 1 & 0 \\
\hline Ward drinking water & 1 & 0 \\
\hline Theatre hot water & 1 & 0 \\
\hline Theatre cold water & 30 & 0 \\
\hline Theatre scrub area & 0 & 1 \\
\hline $\begin{array}{l}\text { Treatment room hot } \\
\text { water }\end{array}$ & 0 & 1 \\
\hline $\begin{array}{l}\text { Treatment room cold } \\
\text { water }\end{array}$ & 0 & 1 \\
\hline $\begin{array}{l}\text { Treatment room } \\
\text { drinking water }\end{array}$ & 0 & 1 \\
\hline Domestic hot water & 200 & 1 \\
\hline Domestic cold water & $>400$ & 2 \\
\hline
\end{tabular}

water, hot water, and cold water from the A\&E treatment room, operating theatre, and ward. Domestic hot and cold water samples were also sampled. Samples were collected immediately after turning on the taps. Nine hundred millilitres of water were collected from each tap supply under investigation into three sterile containers containing sodium thiosulphate (to neutralise chlorine and chlorine compounds) and analysed within six hours of collection for common organisms which could lead to wound infection. Detection limits of 10 organisms/litre were used to screen for coliforms, Staphylococcus aureus, clostridia, pseudomonas, and $\beta$ haemolytic streptococci. The water was filtered for bacteria and then plated on appropriate agar and incubated at $22^{\circ} \mathrm{C}$ and $37^{\circ} \mathrm{C}$ according to the HMSO guidelines on the methods for the examination of water and associated materials. ${ }^{8}$

Two groups of samples were analysed at an eight month interval from each of the areas under investigation.

\section{Results}

The results are summarised in tables 1 and 2 .

There was no growth of coliforms, $S$ aureus, clostridia, pseudomonas, or $\beta$ haemolytic streptococci from any of the samples analysed in either time interval group or at the different incubation temperatures. Although the saprophytic organisms isolated from the department were not identified, the colony count per ml was very low and more importantly, they were non-pathogenic organisms. Total viable bacterial counts at $37^{\circ} \mathrm{C}$ are the most useful water quality indicator and can provide early signs of serious pollution. The results show that the A\&E water supply was not polluted and did not contain pathogenic bacteria. 
Table 2 Bacterial colony count of AछE tap water eight months after sample 1

\begin{tabular}{lcl}
\hline AEE areas investigated & $\begin{array}{l}\text { Colony count/ml at } \\
22^{\circ} \mathrm{C}\end{array}$ & $\begin{array}{l}\text { Colony count/ml at } \\
37^{\circ} \mathrm{C}\end{array}$ \\
\hline Ward hot water & 0 & 0 \\
Ward cold water & 0 & 0 \\
Ward drinking water & 0 & 0 \\
Theatre hot water & 0 & 0 \\
Theatre cold water & 0 & 0 \\
Theatre scrub area & 300 & 0 \\
Treatment room hot & & \\
water & 0 & 0 \\
Treatment room cold & & \\
water & 0 & 0 \\
Treatment room & & \\
drinking water & 0 & 0 \\
Domestic hot water & 0 & 1 \\
Domestic cold water & 7 & 0 \\
\hline
\end{tabular}

\section{Discussion}

Wounds presenting to the $A \& E$ department are considered to be contaminated, and several studies have shown that wound infection correlates well with a bacterial count in tissue of more than $10^{5}$ bacteria per gram of tissue. ${ }^{259}$ There is no evidence that open wounds need to be sterile for them to heal. ${ }^{10}$ Several studies have shown that irrigation decreases the bacterial inoculum in wounds to levels that can be managed by the host defences and lowers the infection rate in contaminated wounds. ${ }^{34}$ Dire and Welsh compared infection rates in open traumatic wounds cleaned with different wound irrigation solutions (including normal saline) and found no statistical difference. Their infection rate following irrigation with normal saline was $6.9 \% .^{3}$ Minor lacerations that are treated at home by irrigation under running tap water usually heal without adverse effects. Topical antiseptics have been used in wound cleansing in the past in an attempt to control the number of micro-organisms. These, however, do not significantly reduce bacterial counts compared to water, and were actually shown to retard wound healing. ${ }^{611}$ Most A\&E departments irrigate wounds with normal saline or sterile water-the latter certainly playing an important role in the management of chemical burns. ${ }^{1213}$

The cost of proprietary normal saline sachets or multidose bottles, although inexpensive per unit, amounts to a significant spending when considering the number of patients with traumatic wounds treated in a busy $A \& E$ department. Tap water would be both easier to use and cheaper.

In our study pathogenic bacteria were not isolated from the tap water supplies in the A\&E department. The few areas where low bacterial counts were isolated were areas where the water supply either originated from water storage tanks or was less frequently used and therefore remaining stagnant, allowing saprophytic (rather than pathogenic) bacterial colonisation, for example, theatre scrub area and domestic supplies.

Although wound infection rates after saline irrigation have been shown to be approximately $6.9 \%$, a study to compare infection rates in wounds following irrigation with tap water to saline would involve very large numbers of patient to produce significant results. ${ }^{3}$

Hospital tap water is not routinely assayed for micro-organisms unless the hospital has its own private water supply or there is doubt about its quality. Water borne infection usually results from defects in plumbing, cross connections, back flow, and pressure fluctuations in the water distribution system. Although there is a theoretical risk of wound infection from a heavily contaminated water supply, the inoculum during wound irrigation would have to be substantial to produce iatrogenic infection in a healthy individual. The National Rivers Authority in England Wales, and the River Purification Authorities in Scotland, have a statutory responsibility for monitoring and upgrading the quality of surface waters and for the protection of ground water supplies. ${ }^{8}$ Although there are strict water purification guidelines which monitor contamination by pathogenic bacteria, water quality may vary from day to day. If hospital tap water was to be used for irrigating wounds, then occasional monitoring of water microbiology could be performed by the hospital or department concerned.

\section{CONCLUSION}

Hot, cold, or drinking tap water in the $A \& E$ department did not contain pathogenic bacteria and therefore can reasonably be used to irrigate traumatic open wounds. At present approximately $£ 5000$ of saline sachets are used annually in the cleaning and irrigation of traumatic wounds in our A\&E department. As a result of this study and after careful discussion with the control of infection committee we shall in future use tap water in preference to normal saline for irrigating open traumatic wounds.

1 Altemeier WA, Gibbs EW. Bacterial flora of fresh accidental wounds. Surg Gynaecol Obstet 1944;78:164-8.

2 Rodeheaver GT, Pettry D, Thacker JG, Edgerton MT, Edlich RF. Wound cleansing by high pressure irrigation. Surg Gynecol Obstet 1975;141:357-62.

3 Dire DJ, Welsh AP. A comparison of wound irrigation solutions used in the emergency department. Ann Emerg Med tions used in the

4 Longmire AW, Broom LA, Burch J. Wound infection following high pressure syringe and needle irrigation. Am J Emerg Med 1987;5:179-81

5 Hamer ML, Robson MC, Krizek TJ. Quantitative bacterial analysis of comparative wound irrigations. Ann Surg 1975; 181:819-21.

6 Johnson AR, White AC, McAnally B. Comparison of common topical agents for wound treatment: cytotoxicity for human fibroblasts in culture. Wounds 1989;1:186-92.

7 Oberge M, Lindsey D. Do not put hydrogen peroxide or povidone iodine into wounds! Am J Dis Child 1987;141: 27-8.

8 Department of Health.. The microbiology of water 1994. Part $1-$ Drinking water. Report on Public Health and Medical
Subjects No 71 . Methods for the examination of waters Subjects No 71. Methods for the examination
and associated materials. London: HMSO, 1994.

9 Robson MC, Duke WF, Krizek TJ. Rapid bacterial screening in the treatment of civilian wounds. J Surg Res ing in the treat

10 Leaper DJ. Prophylactic and therapeutic role of antibiotics in wound Pare. Am J Surg 1994;167:15-19S.

11 Mertz PM, Alverez OM, Smerbeck RV, Eaglstein WH. A new in vitro model for the evaluation of topical antiseptics on superficial wounds: the effect of $70 \%$ alcohol and povidone iodine solution. Arch Dermatol 1984;120:58-62.

12 Mozingo DN, Smith AA, McManus WF. Chemical burns. J Trauma 1988;28:642-7.

13 Ryan TJ. Wound healing in the developing world. Dermatol Clin 1993;11:795-800. 